\title{
Dendrimer-protein interactions versus dendrimer-based nanomedicine
}

\author{
Dzmitry Shcharbin $^{\mathrm{a}, *}$, Natallia Shcharbina ${ }^{\mathrm{b}}$, Volha Dzmitruk ${ }^{\mathrm{a}}$, \\ Elzbieta Pedziwiatr-Werbicka ${ }^{c}$, Maksim Ionov $^{c}$, Serge Mignani ${ }^{\mathrm{d}}$, F. Javier de la Mata e,f, \\ Rafael Gómez ${ }^{\text {,f }}$, Maria Angeles Muñoz-Fernández ${ }^{\mathrm{f}, \mathrm{g}, \mathrm{h}, \mathrm{i}}$, Jean-Pierre Majoral ${ }^{\mathrm{j}, \mathrm{k}}$, \\ Maria Bryszewska ${ }^{c}$ \\ a Institute of Biophysics and Cell Engineering of NASB, Minsk, Belarus \\ ${ }^{\mathrm{b}}$ Clinics at the MAZ Company, Minsk, Belarus \\ c Department of General Biophysics, Faculty of Biology and Environmental Protection, University of Lodz, Lodz, Poland \\ d Universiteí Paris Descartes, Laboratoire de Chimie et de Biochimie pharmacologiques et toxicologique, Paris, France \\ e Departamento Química Orgánica y Química Inorgánica, Universidad de Alcalá, Alcalá de Henares, Spain \\ ${ }^{\mathrm{f}}$ Networking Research Center on Bioengineering, Biomaterials and Nanomedicine, CIBER-BBN, Spain \\ g Laboratorio InmunoBiología Molecular, Hospital General Universitario Gregorio Marañón, Madrid, Spain \\ ${ }^{\mathrm{h}}$ Instituto de Investigación Sanitaria Gregorio Marañón (IiSGM), Madrid, Spain \\ ${ }^{\mathrm{i}}$ Spanish HIV-HGM BioBank, Madrid, Spain \\ j Laboratoire de Chimie de Coordination, CNRS, Toulouse, France \\ ${ }^{\mathrm{k}}$ Université de Toulouse, Toulouse, France
}

\section{A R T I C L E I N F O}

\section{Article history:}

Received 3 November 2016

Received in revised form 22 January 2017

Accepted 23 January 2017

Available online 31 January 2017

\section{Keywords:}

Dendrimer

Protein

Interaction

Mechanisms

Nanomedicine

\begin{abstract}
A B S T R A C T
Dendrimers are hyperbranched polymers belonging to the huge class of nanomedical devices. Their wide application in biology and medicine requires understanding of the fundamental mechanisms of their interactions with biological systems. Summarizing, electrostatic force plays the predominant role in dendrimer-protein interactions, especially with charged dendrimers. Other kinds of interactions have been proven, such as H-bonding, van der Waals forces, and even hydrophobic interactions. These interactions depend on the characteristics of both participants: flexibility and surface charge of a dendrimer, rigidity of protein structure and the localization of charged amino acids at its surface. $\mathrm{pH}$ and ionic strength of solutions can significantly modulate interactions. Ligands and cofactors attached to a protein can also change dendrimer-protein interactions. Binding of dendrimers to a protein can change its secondary structure, conformation, intramolecular mobility and functional activity. However, this strongly depends on rigidity versus flexibility of a protein's structure. In addition, the potential applications of dendrimers to nanomedicine are reviwed related to dendrimer-protein interactions.
\end{abstract}

(c) 2017 Elsevier B.V. All rights reserved.

\section{Contents}

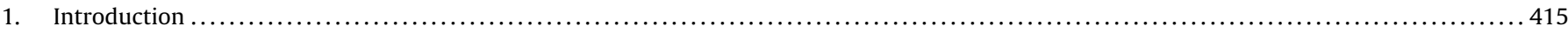

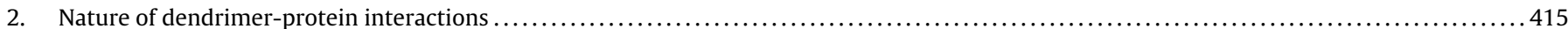

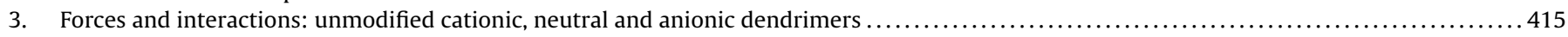

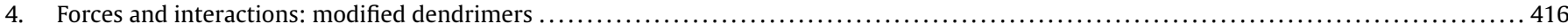

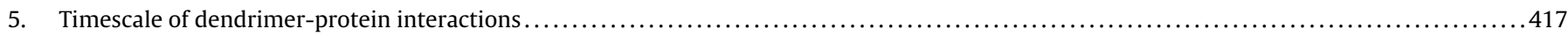

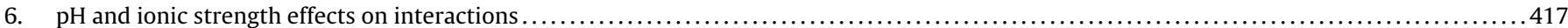

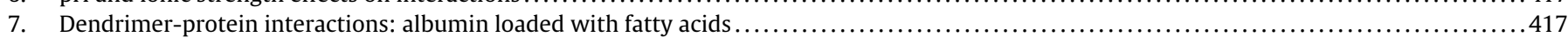

\footnotetext{
* Corresponding author at: Institute of Biophysics and Cell Engineering of NASB, Akademicheskaja Str. 27, 220072, Minsk, Belarus.

E-mail address: shcharbin@gmail.com (D. Shcharbin).
} 


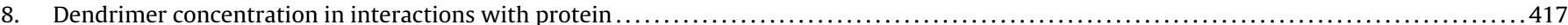

9. Protein structure flexibility: the impact of dendrimers on a protein secondary structure, conformation and intramolecular mobility ......... 418

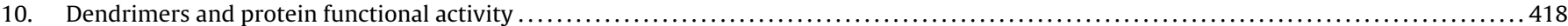

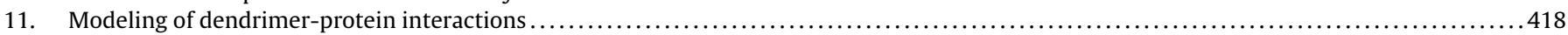

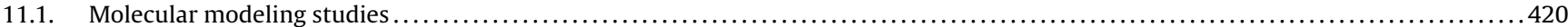

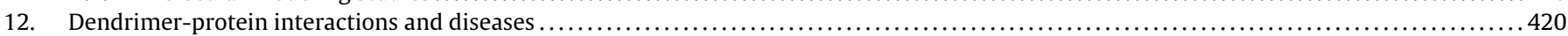

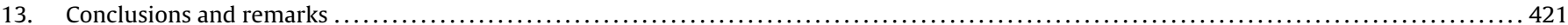

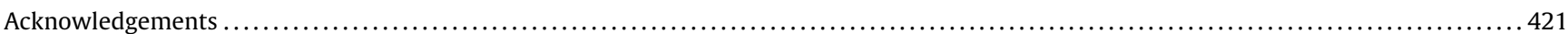

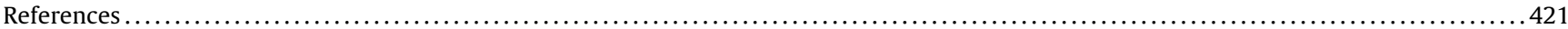

\section{Introduction}

Application of nanoparticles in medicine leads to their interaction with blood, with serum containing $>2392$ proteins $[1,2]$, or cerebrospinal fluid (CSF) containing $>2630$ proteins [3]. If a nanoparticle has a rigid surface, a large size (higher than a protein globule) and a strong charge, it can absorb proteins at its surface by means of electrostatic or van der Waal's forces, hydrophobic interactions or hydrogen bonds, forming a protein coating - a 'protein corona' [4-6]. This can determine absorption, distribution, biocompatibility, excretion and biological activity of nanoparticles [4-6]. But what is happen if the nanoparticle is small and 'soft', e.g. dendrimer [7]? Dendrimers are hyperbranched polymers belonging to a class of nanomaterials [7-19]. They are globular in shape with topological structure formed by monomeric subunit branches diverging on all sides from the central core. The following features can be distinguished in dendrimers: (i) multivalent surfaces containing numerous potentially active sites, (ii) envelopes surrounding the core, and (iii) a core with attached dendrons [7-13]. With regard to modifications, $>200$ kinds of dendrimers have been synthesized [7-19]. None of the most widespread families can be distinguished: poly(amide amine) (PAMAM) dendrimers are based on the ethylenediamine core, and their branches consist of methyl acrylate and ethylenediamine [7]. Half generations of PAMAM dendrimers have carboxyls whereas complete generations have amino groups on their surface. Polypropyleneimine (PPI) dendrimers are based on the butylenediamine core and polypropyleneimine monomers [8,9]. Besides PPI, another popular abbreviation of these dendrimers is DAB (diaminobutyl), the name of the core. In phosphorus-based dendrimers, the phosphorus atoms occur in the core and branches of these dendrimers $[8,9]$. Carbosilane dendrimers have a silicon core and ammonium or amino groups at their periphery [8]. Poly(lysine) dendrimers are based on lysine and have poly(lysine) branches and surface groups, whereas poly(ester), poly(glycerol), melamine and triazine dendrimers are based on their corresponding monomer units [8]. Among them, PAMAM (Starburst $^{\mathrm{TM}}$ ), poly-etherhydroxyl-amine PEHAM (Priostar ${ }^{\mathrm{TM}}$ ), PPI (Astramol ${ }^{\mathrm{TM}}$ ) and phosphorus based dendrimers are commercially available. The architecture and properties of dendrimers depend on the generation. Low generations of dendrimers have an open, flattened and asymmetric shape, but the structure becomes globular and densely packed on the periphery as the generation increases. There are empty cavities inside dendrimers. Another important feature of dendrimers is their monodispersity. The classical polymerization process is usually random and produces molecules of different sizes, but the size and molecular mass of dendrimers can be specifically controlled during synthesis. Finally, dendrimers possess many functional end groups responsible for their high solubility and reactivity [7-13]. Based on their unique features, the term 'dendrimer space concept' is an approach to a new paradigm for medicinal chemists to identify novel dendrimer-based drugs [13]. We attempt here systemize the mechanisms of interactions between dendrimers and proteins as the basis for applications of dendrimer use in modern nanomedicine.

\section{Nature of dendrimer-protein interactions}

To understand the basics of dendrimer-protein interactions, Higashi et al. [20] synthesized a peptide-shelled dendrimer containing a poly(L-glutamic acid) segment grafted on the 3rdgeneration PAMAM dendrimer and analyzed its interaction with hydrophobic $\alpha$-amino acids (Trp, Phe, and Tyr). This dendrimer bound to $\alpha$-amino acids with positive cooperativity on the basis of a Hill plot; as a result, D-isomers preferentially bound to the $\alpha$-helical segments relative to L-isomers [20]. Using electron paramagnetic resonance, Ottaviani et al. [21] studied the interaction between cationic PAMAM- $\mathrm{NH}_{2}$ dendrimers of 2nd (g2) and 6th (g6) generations, amino acids (Gly, Glu, Arg, Leu) and proteins ( $\alpha$ chymotrypsin, albumin). The interaction between dendrimers and amino acids was described by as a series: Glu $<$ Gly $<$ Leu $\approx \operatorname{Arg}[21]$. For the zwitterionic Leu, this interaction was determined by a synergistic effect of electrostatic forces between amino groups of a dendrimer and the carboxylate group of Leu, and by hydrophobic interactions of the Leu side-chain with the dendrimer sites at low polarity ( $-\mathrm{CH}_{2}-\mathrm{CH}_{2}-$ groups) [21]. The formation of stable ion pairs between Glu and the dendrimer's internal basic tertiary nitrogens was proposed [21]. The significant $\mathrm{pH}$ dependence of the interactions between dendrimers and amino acids indicated a role of electrostatic forces [21]. The interaction between dendrimers and $\alpha$-chymotrypsin was based on both electrostatic forces due to its high isoelectric point (8.3) and hydrophobic interactions because of the presence of a hydrophobic pocket (a hydrophobic amino acids $-e . g$. Leu) at the substrate linking site [21]. In contrast, the interaction between dendrimers and serum albumin examined by electron paramagnetic resonance was significantly weaker than that of chymotrypsin. For albumin, these authors proposed the preferential role of the weak dipole-dipole or ion-dipole interactions between the albumin hydrophilic residues and the dendrimer surface [21].

\section{Forces and interactions: unmodified cationic, neutral and anionic dendrimers}

Electrostatic forces are predominant in interactions of cationic and anionic dendrimers with proteins (Tables 1 and 2, Fig. 1).

The role of different types of dendrimer-protein interactions can be ranged as follows: (i) electrostatic forces between charged dendrimer terminal groups and protein residues, (ii) hydrogen bonding between dendrimer internal groups (e.g., amide moiety where the carbonyl $\mathrm{O}$ acts as donor and the amide $\mathrm{H}$ as acceptor), and protein amino acid residues, (iii) hydrophobic interactions between the nonpolar dendrimer and HSA groups, and (iv) specific interactions between dendrimer carboxylic groups and protein aliphatic acid binding sites [22]. In contrast, hydrophobic interactions and the Hofmeister effect are more important for interaction between albumins and neutral PAMAM-OH g4 dendrimer, whereas the electrostatic ones are preferential in interactions between albumins and charged dendrimers [23] (Tables 1 and 2). In summary, a charge on dendrimers significantly increases their interaction with proteins compared with neutral ones. 
Table 1

Dendrimer-protein interactions (part 1).

\begin{tabular}{|c|c|c|c|}
\hline Protein & Dendrimer & Result and mechanisms of an interaction & Ref. \\
\hline Lectin concanavalin A & $\begin{array}{l}\text { Mannosylated dendrimers or } \\
\text { lactose-containing dendrimers }\end{array}$ & $\begin{array}{l}\text { Maximum inhibitory potency of dendrimers showed the } \\
\text { plateau to occur at a constant valency of mannoside } \\
\text { residues or was generation-dependent (for lactose-based } \\
\text { dendrimers) indicating the importance of stoichiometry } \\
\text { in this process. }\end{array}$ & {$[24,25,67]$} \\
\hline $\begin{array}{l}\text { Bovine and human serum } \\
\text { albumins }\end{array}$ & $\begin{array}{l}\text { Cationic, neutral and anionic } \\
\text { PAMAM dendrimers; } \\
\text { Carbosilane dendrimers }\end{array}$ & $\begin{array}{l}\text { The main mechanisms: (i) electrostatic forces between } \\
\text { charged dendrimer terminal groups and protein residues, } \\
\text { (ii) hydrogen bonding between dendrimer internal groups } \\
\text { (e.g., amide moiety where the carbonyl O act as donor and } \\
\text { the amide H as acceptor), and protein amino acid residues, } \\
\text { (iii) hydrophobic interactions between the nonpolar } \\
\text { dendrimer and HSA groups, and (iv) specific interactions } \\
\text { between dendrimer carboxylic groups and protein } \\
\text { aliphatic acid binding sites. The secondary structure is not } \\
\text { changed by cationic but changed by anionic dendrimers. } \\
\text { The significant changes in conformation and } \\
\text { intramolecular mobility were observed. Serum albumins } \\
\text { had 5-6 non-specific anionic regions (consisting of local } \\
\text { groups of negatively charged amino acids) can be used for } \\
\text { binding of positively charged dendrimers. }\end{array}$ & $\begin{array}{l}{[40,41,21,26,73,23} \\
38,42,32,74,27,22,75,82\end{array}$ \\
\hline Alpha-chymotrypsin & Cationic PAMAM dendrimers & $\begin{array}{l}\text { The interaction is based both on electrostatic forces due } \\
\text { to its high isoelectric point ( } 8.3 \text { ), and on hydrophobic } \\
\text { interactions because of the presence of a hydrophobic } \\
\text { pocket (hydrophobic amino acids such as Leu) at the } \\
\text { substrate linking site. }\end{array}$ & {$[21,43]$} \\
\hline Acetylcholinesterase & $\begin{array}{l}\text { Cationic, neutral and anionic } \\
\text { PAMAM g4 dendrimers }\end{array}$ & $\begin{array}{l}\text { Electrostatic as well as hydrophobic interactions. The } \\
\text { changes in a protein conformation were observed. }\end{array}$ & {$[76]$} \\
\hline $\begin{array}{l}\text { Ribonuclease } \mathrm{T}_{1} \text {, rabbit muscle } \\
\text { aldolase, horse liver alcohol } \\
\text { dehydrogenase, azurin, } \\
\text { alkaline phosphatase from } \\
\text { E.Coli, human } \\
\text { gamma-globulins }\end{array}$ & $\begin{array}{l}\text { Cationic, neutral and anionic } \\
\text { PAMAM g5 dendrimers }\end{array}$ & $\begin{array}{l}\text { Electrostatic forces play a preeminent role in such an } \\
\text { interaction, a contribution that becomes strongly } \\
\text { attenuated at high ionic strength. The significant changes } \\
\text { in a protein intramolecular mobility were observed. }\end{array}$ & {$[38]$} \\
\hline
\end{tabular}

Table 2

Dendrimer-protein interactions (part 2).

\begin{tabular}{|c|c|c|c|}
\hline Protein & Dendrimer & Result and mechanisms of an interaction & Ref. \\
\hline $\begin{array}{l}\text { Insulin, } \\
\text { ribosomal } \alpha / \beta \text { protein } S 6 \text {, } \\
\text { cutinase, all- } \beta \text { protein Tnfn3, } \\
\text { hen egg white lysozyme }\end{array}$ & $\begin{array}{l}\text { PPI dendrimers (unmodified, } \\
\text { modified by guanidinium } \\
\text { group or a urea group), } \\
\text { cationic PAMAM dendrimers }\end{array}$ & $\begin{array}{l}\text { Dendrimer-insulin interactions were determined by } \\
\text { electrostatic forces. The impact on the secondary } \\
\text { structure and thermal stability of insulin was found. The } \\
\text { dependence on a protein nature was found. }\end{array}$ & [28] \\
\hline Collagen & Cationic PAMAM dendrimers & $\begin{array}{l}\text { Collagen cross-linked by dendrimers exhibited a higher } \\
\text { denature temperature and higher resistance against } \\
\text { collagenase digestion compared with non-modified one. }\end{array}$ & {$[77]$} \\
\hline Cytochrome $c$ & $\begin{array}{l}\text { Anionic carboxilated PAMAM } \\
\text { dendrimers }\end{array}$ & $\begin{array}{l}\text { Charged dendrimers bound to a protein's interfacial area } \\
\text { without affecting the protein's secondary structure }\end{array}$ & [43] \\
\hline Actin & $\begin{array}{l}\text { Cationic poly(lysine) } \\
\text { dendrimers }\end{array}$ & $\begin{array}{l}3 \text { types of interactions: (a) at low concentration } \\
(0.01-1 \mu \mathrm{g} / \mathrm{ml}) \text { dendrimers behaved like } \mathrm{G} \text {-actin-binding } \\
\text { protein; (b) at higher concentrations }(10 \mu \mathrm{g} / \mathrm{ml}) \text { they } \\
\text { accelerated the time course in the exponential phase; (c) } \\
\text { in the range } 10-100 \mu \mathrm{g} / \mathrm{ml} \text { they accelerated the } \\
\text { polymerization by shortening both the lag phase and } \\
\text { exponential phase. }\end{array}$ & [33] \\
\hline Alpha-chymotrypsinogen A & Cationic PAMAM dendrimers & $\begin{array}{l}\text { Two main effect were elucidated: enhancement of } \\
\text { conformational stability and reduction of } \\
\text { protein-protein association due to crowding of } \\
\text { dendrimers around the protein surface }\end{array}$ & [45] \\
\hline $\begin{array}{l}\text { Horse liver alcohol } \\
\text { dehydrogenase, } \\
\text { lysozyme }\end{array}$ & $\begin{array}{l}\text { Unmodified and maltose } \\
\text { modified PPI g4 dendrimers }\end{array}$ & $\begin{array}{l}\text { Electrostatic forces played the main role in these } \\
\text { interactions; however, additional interactions have been } \\
\text { proved such as either H-bonding or van der Waals forces, } \\
\text { or even hydrophobic interactions. Maltose modified } \\
\text { dendrimers did not impact the secondary structure of a } \\
\text { protein in contrast to unmodified cationic PPI dendrimers. }\end{array}$ & {$[78,79]$} \\
\hline $\begin{array}{l}\text { Aspartate transaminase, } \\
\text { alkaline phosphatase and } \\
\text { L-lactic dehydrogenase }\end{array}$ & $\begin{array}{l}\text { Cationic PAMAM and } \\
\text { phosphorus-based dendrimers }\end{array}$ & $\begin{array}{l}\text { Electrostatic forces played the main role in these } \\
\text { interactions. The impact was strongly depended on a } \\
\text { protein nature. }\end{array}$ & {$[36,37]$} \\
\hline
\end{tabular}

\section{Forces and interactions: modified dendrimers}

The modification of dendrimers by sugars significantly changed their interaction with proteins [24,25] (Tables 1 and 2). The maximum inhibitory potency of mannosylated dendrimers showed the plateau to occur at a constant valency of mannoside residues or was generation-dependent (for lactose-based dendrimers) indicating the importance of stoichiometry in this process [24,25]. Sugar-persubstituted PAMAM dendrimers of 3rd and 5th generations did not change the secondary structure of albumin [26]. 


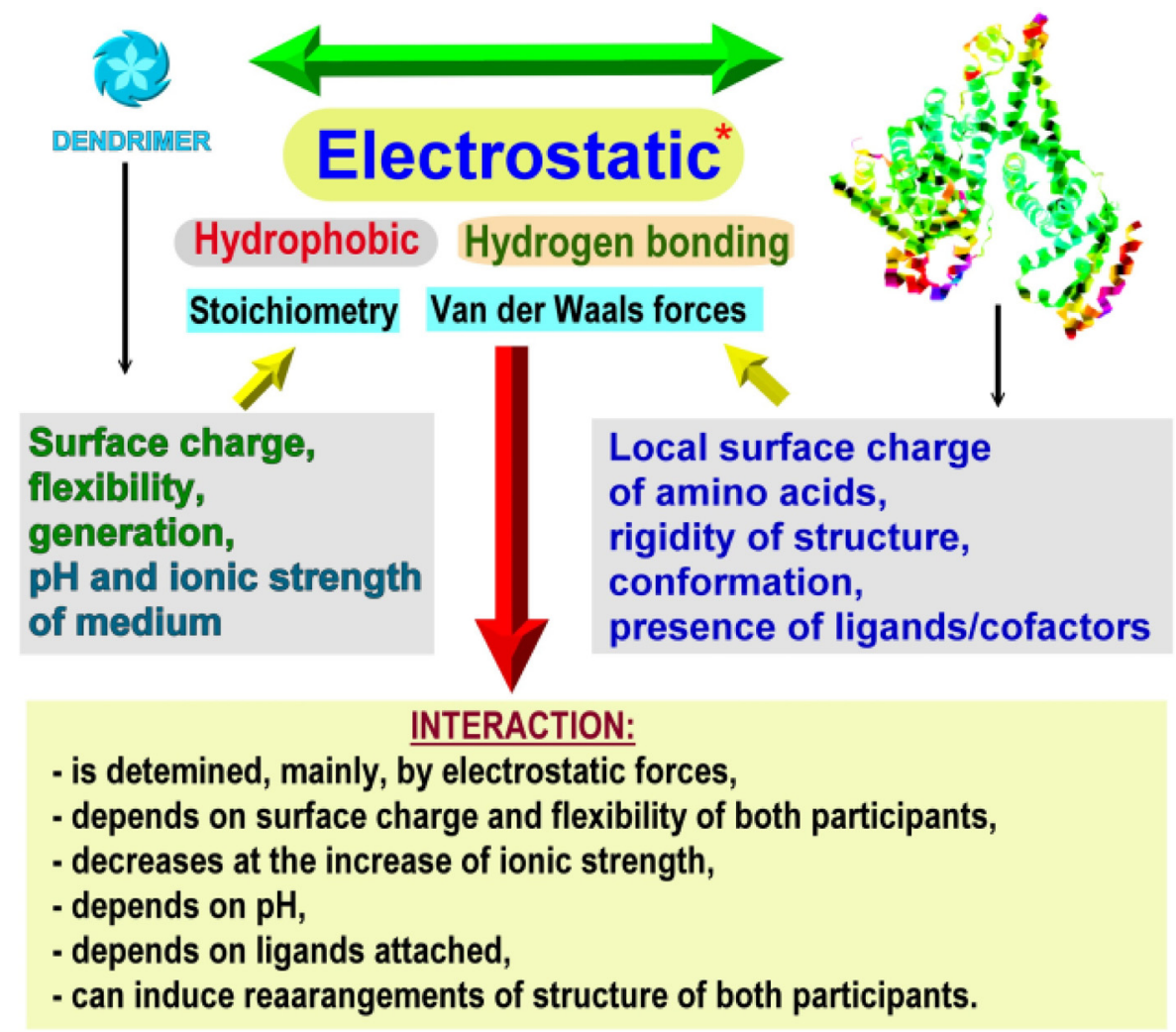

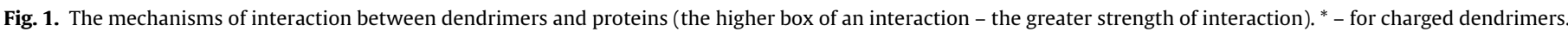

In contrast, cationic PAMAM g3 and g4 dendrimers modified by polyethylene glycol (PEG) significantly interacted with on serum albumin secondary structure and conformation [27]. PPI dendrimers (unmodified, modified by guanidinium group or a urea group) altered insulin in a different manner. Most of them changed both secondary structure and the thermal stability of insulin [28]. In Summary, the nature of surface groups of modified dendrimers is extremely important in the dendrimer-protein interactions.

\section{Timescale of dendrimer-protein interactions}

Camarada et al. [29] investigated the timescale of dendrimerprotein interactions using L-chain ferritin and the cationic PAMAM g4 dendrimer as an example. Electrostatic forces were predominant during the first contact of a dendrimer with a protein, occurring within $4.5 \mathrm{~ns}$. Other types of interactions (hydrophobic, van der Waals, H-bonding, etc.) occur at the second step in >100 ns [29] (Fig. 2). Similar results were observed in molecular modeling studies on the interaction of dendrimers with drugs, nucleic acids, proteins and lipid membranes, reviewed in detail by Martinho et al. [30].

\section{6. pH and ionic strength effects on interactions}

Following interactions between cationic, neutral and anionic PAMAM g4 dendrimers and serum albumins at different $\mathrm{pHs}$ and ionic strength of the solution showed interactions were $\mathrm{pH}$ dependent [23]. For cationic dendrimers, there was a bell-shaped character of their interaction with serum albumins (maximum at $\mathrm{pH}$ 7.4) [23]. This effect can be explained by pH-dependent ionization both of the dendrimer and protein groups [23]. Addition of salts led to significant decrease of dendrimer-protein interactions for all the dendrimers studied, caused by (a) tightening of protein con- formation; (b) increase in the screening by a counterion-polyion coupling mechanism; (c) the Hofmeister effect [23,38].

\section{Dendrimer-protein interactions: albumin loaded with fatty acids}

In serum, albumins exist as proteins loaded with fatty acids (up $30 \% \mathrm{v} / \mathrm{v}$ ) [31]. Shcharbin et al. [31] analyzed the interaction between cationic PAMAM g2 and g6 dendrimers and bovine serum albumin (free or loaded with fatty acids). Fatty acids decreased their interaction in a manner dependent on the number of fatty acid molecules bound [32]. PAMAM dendrimers also competed with BSA for fatty acids. If 2 or 3 fatty acids are loaded per protein, this can lead to the extraction of fatty acids from the BSA on to the PAMAM dendrimer [32]. Cofactors of other proteins have a similar effect.

\section{Dendrimer concentration in interactions with protein}

Ruenraroengsak and Florence [33] explored the effects of the presence of cationic poly(lysine) dendrimers at different concentrations. Three phases for actin polymerization proved to be concentration-dependent: (a) at low concentration $(0.01-1 \mu \mathrm{g} / \mathrm{ml})$ dendrimers behaved like G-actin-binding protein - bound with the actin monomer, causing a reduction in the concentration of the latter in the system, thereby lengthening both the lag and the exponential phases; (b) at higher concentration $(10 \mu \mathrm{g} / \mathrm{ml})$ they accelerated the time-course in the exponential phase by inducing actin fragmentation (e.g. "severing" protein); (c) and in the range $10-100 \mu \mathrm{g} / \mathrm{ml}$ they accelerated the polymerization by shortening both the lag and exponential phases (e.g. "nucleating" proteins) [33]. Nowacka et al. [34] found the stabilizing effect of small concentrations (up to $1.4 \mu \mathrm{g} / \mathrm{ml}$ ) of cationic PAMAM g3 and g4 dendrimers on aggregation of insulin: cationic dendrimers decreased insulin aggregation [34]. In contrast, PPI dendrimers at high con- 
centrations (up to $450 \mu \mathrm{g} / \mathrm{ml}$ ) significantly destroyed the thermal stability of insulin [28].

\section{Protein structure flexibility: the impact of dendrimers on a protein secondary structure, conformation and intramolecular mobility}

Numerous reports (Tables 1 and 2) indicate that dendrimers can impact on a protein secondary structure, conformation and intramolecular mobility. On the one hand, dendrimers can bind to many regions of the protein surface, tightening the protein structure and restricting the molecular motion of the macromolecule; on the other hand, they can unfold a globular protein (Tables 1 and 2). The effect of a dendrimer depends on its nature and charge (see above). The most important issue is the flexibility of the protein structure [35-37], which is crucial in determining a functional response of a protein, starting from absence of any effect finishing dendrimer-driven changes in a protein secondary structure, conformation and function [36]. For example, cationic PAMAM g3 and g4 dendrimers did no affect alkaline phosphatase from $E$. coli that has a rigid structure, but affected lactate dehydrogenase and aspartate transaminase [36-38].

\section{Dendrimers and protein functional activity}

Protein functional activity in the presence of dendrimers significantly depends both on the flexibility of protein structure (see (Table 3) p. 8), and on the nature and type of dendrimer. For example, PAMAM-OH g4 and g5 dendrimers decreased $\mathrm{Na}^{+} / \mathrm{K}^{+}$ ATPase and $\mathrm{Ca}^{2+}$ ATPase the activity, whereas the PAMAM-OH g5 dendrimer activated $\mathrm{Mg}^{2+}$ ATPase [39]. The cationic PAMAM g4, phosphorous g4 and carbosilane g3 dendrimers also had completely different effects on the activity of human serum enzymes (alkaline phosphatase, lactate dehydrogenase, aspartate transaminase, $\mathrm{\gamma}$-glutamyl transferase, cholinesterase, alanine aminotransferase, amylase, creatine kinase and 2-hydroxybutyrate dehydrogenase) starting with a decrease of enzyme activity and finishing activation depending on the enzyme and the interacting dendrimer (chemical structure, surface charge and flexibility) [35].

\section{Modeling of dendrimer-protein interactions}

The first model was proposed by Klajnert and Bryszewska and was based on electrostatic forces [40,41] (Fig. 3).

In 2007, Shcharbin et al. [42], on the basis of interaction between cationic PAMAM dendrimer and serum albumins, proposed a new model in which the existence of non-specific binding sites for a dendrimer binding was proven (5-6 'binding sites' for albumin). These 'sites' are based on local concentrations of charged amino acid residues at the protein surface [42]. In 2010, Chiba et al. [43] proposed a 'hot spot' model of dendrimer-protein interactions also based on 'hot spots' of a protein globule that bound dendrimers. In this model (Fig. 3), protein inhibition can be determined by (a) simple hot spot binding, where the negatively charged dendrimer binds to the positively charged hotspot region (the dendrimer may change shape to maximize binding);. (b) As with (a), but to maximize binding the protein changes shape (denaturation). (c) The dendrimer binds to a remote site, resulting in denaturation and deactivation [43]. In 2015, Shcharbin et al. [36] (Fig. 4) proposed a model of 'Dendrimers and Flexible Proteins' in which at least 3 different types of interaction occur dependent on the nature of a protein. First, the 'dendrimer corona' has no effect on proteins with rigid structures with their active sites buried deep inside. Regarding secondary structure of enzymes, their conformation is not perturb, all interactions occur at the surface of a globular protein, and there

\section{Timescale}

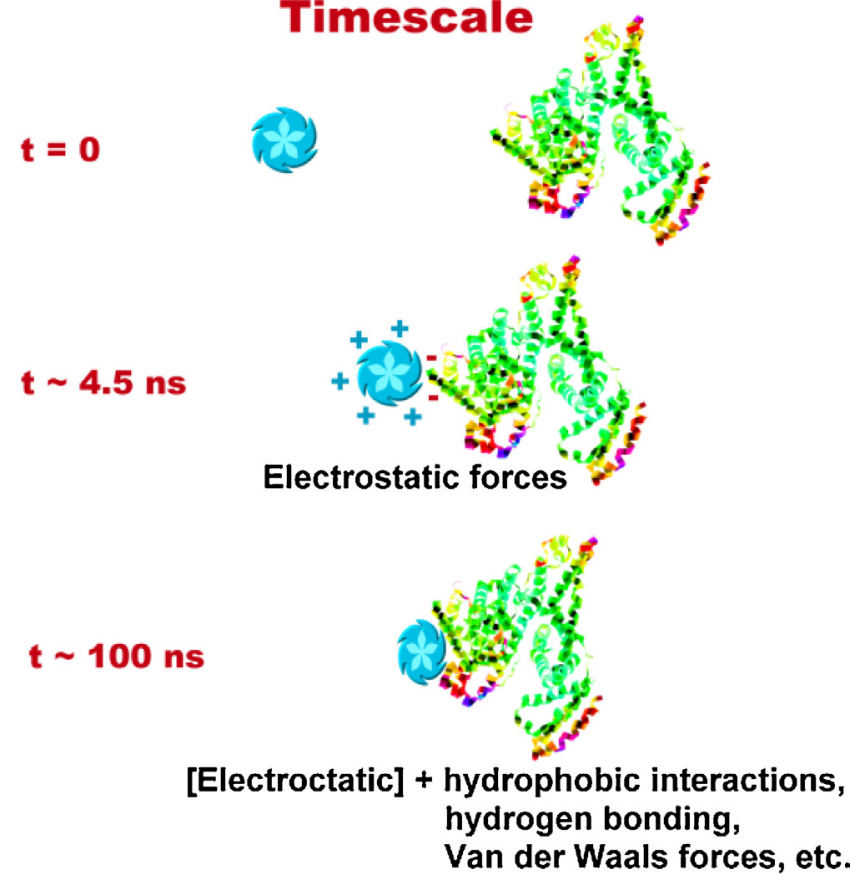

Fig. 2. The timescale of the interaction between dendrimers and proteins [29].
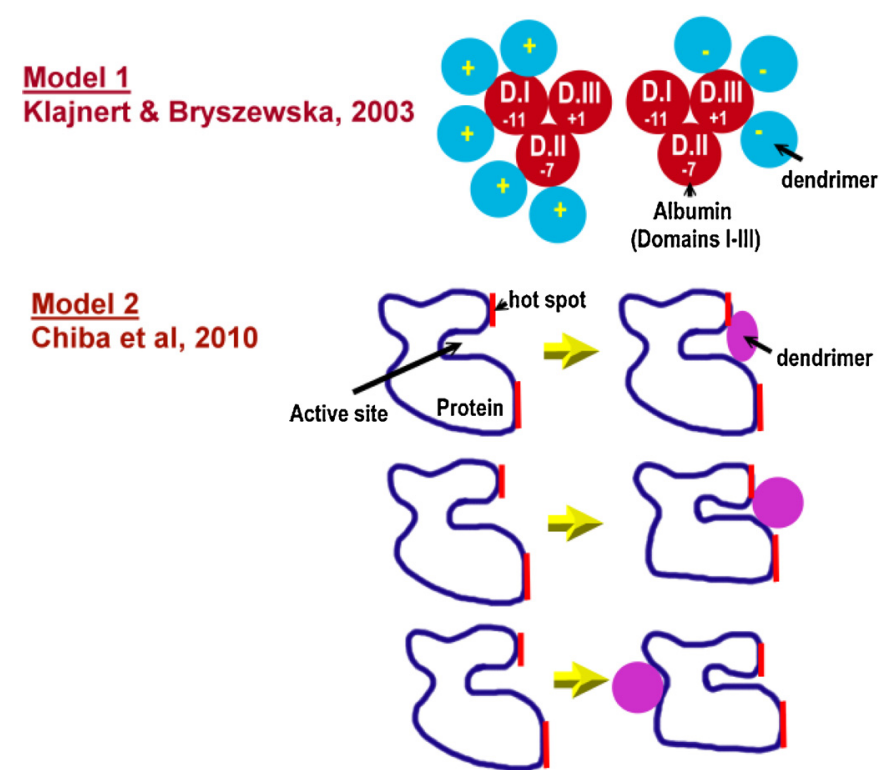

Fig. 3. The different models of the dendrimer-protein interactions. Model 1 is based on electrostatic forces. Model 2 is based on 'hot spots' of a protein globule that bound dendrimers. In this model, protein inhibition can be determined by (a) simple hot spot binding, where the negatively charged dendrimer binds to the positively charged hotspot region (the dendrimer may change shape to maximize binding).(b) As with (a), but to maximize binding the protein changes shape (denaturation). (c) The dendrimer binds to a remote site, resulting in denaturation and deactivation.

was no effect on enzyme activity. Second, the 'dendrimer corona' affects the structure of flexible proteins without changing their enzyme activity, i.e. provided the active site is deeply buried. Third, the 'dendrimer corona' changes both structure and enzyme activity of flexible proteins having surface-based active centers [35,36].

In 2008, Licata and Tkachenko [44] proposed a special model for the interactions between folic acid-conjugated dendrimers and receptor proteins in which a dendrimer with a number of keys (e.g., folic acids) interacts with locks (e.g., folate-binding proteins) at the 
Table 3

The impact of dendrimers on a protein functional activity.

\begin{tabular}{|c|c|c|c|}
\hline Protein & Dendrimer & Protein functional activity & Ref. \\
\hline Acetylcholinesterase & $\begin{array}{l}\text { Cationic, neutral and anionic } \\
\text { PAMAM g4 dendrimers }\end{array}$ & $\begin{array}{l}\text { Decrease of enzyme activity by dendrimers. A negative } \\
\text { charge of acetylcholinesterase active catalytic centre is the } \\
\text { reason why its activity may be inhibited by cationic } \\
\text { ligands. }\end{array}$ & {$[76]$} \\
\hline Human erythrocyte ATPases & $\begin{array}{l}\text { Hydroxylated PAMAM-OH g3, } \\
\text { g4, g5 dendrimers }\end{array}$ & $\begin{array}{l}\text { The decrease (20-30\%) of the activity of } \mathrm{Na}^{+} / \mathrm{K}^{+} \text {ATPase } \\
\text { and } \mathrm{Ca}^{2+} \text { ATPase was observed. In contrast, PAMAM-OH g5 } \\
\text { dendrimer was able to activate } \mathrm{Mg}^{2+} \text { ATPase. }\end{array}$ & [39] \\
\hline Porcine pepsin & $\begin{array}{l}\text { Cationic, neutral and anionic } \\
\text { PAMAM g4 dendrimers }\end{array}$ & $\begin{array}{l}\text { The data showed that cationic and neutral PAMAM g4 } \\
\text { dendrimers were able to inhibit enzyme activity of } \\
\text { pepsin; both of them were able to interact with both, an } \\
\text { enzyme and an enzyme-substrate complex. }\end{array}$ & [80] \\
\hline 9 human serum enzymes & $\begin{array}{l}\text { Cationic PAMAM g4, } \\
\text { phosphorous g4 and } \\
\text { carbosilane g3 dendrimers }\end{array}$ & $\begin{array}{l}\text { Human serum enzymes: alkaline phosphatase, human } \\
\text { lactate dehydrogenase, human aspartate transaminase, } \\
\text { human gamma glutamyl transferase, cholinesterase, alanine } \\
\text { aminotransferase, amylase, creatine kinase, } \\
\text { 2-hydroxybutyrate dehydrogenase. The impact of cationic } \\
\text { dendrimers on enzymes' activity depended strongly on a } \\
\text { protein nature: inhibition, activation or no effect were } \\
\text { observed. }\end{array}$ & {$[35,36]$} \\
\hline L-chain ferritin & Cationic PAMAM g4 dendrimer & $\begin{array}{l}\text { PAMAM g4 significantly (in } 7 \text { times) decreased the iron } \\
\text { storage by L-ferritin. }\end{array}$ & [29] \\
\hline Gamma-globulin & $\begin{array}{l}\text { Cationic, neutral and anionic } \\
\text { PAMAM dendrimers }\end{array}$ & $\begin{array}{l}\text { Dendrimers inhibited the complement activation activity } \\
\text { of gamma-globulin. }\end{array}$ & [81] \\
\hline
\end{tabular}

\section{Model 3: 'Dendrimers and flexible proteins'}

Shcharbin et al, 2007-2015

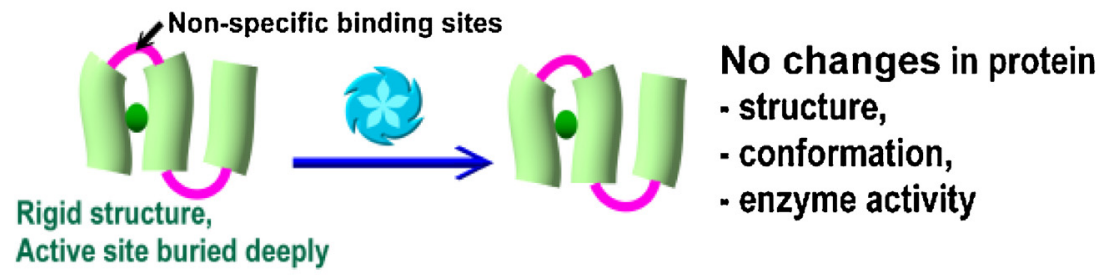

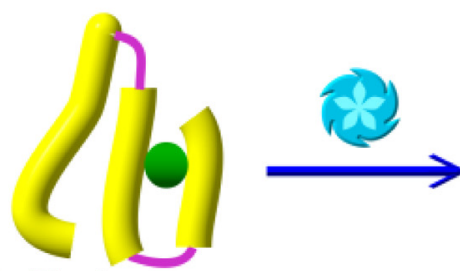

Flexible structure,

Active site buried deeply or placed far from dendrimer 'binding sites'

\section{Changes in protein}

- structure,

- conformation

do not correspond

with enzyme activity

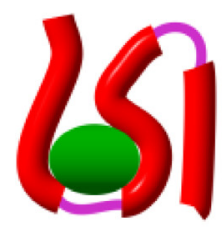

Flexible structure,

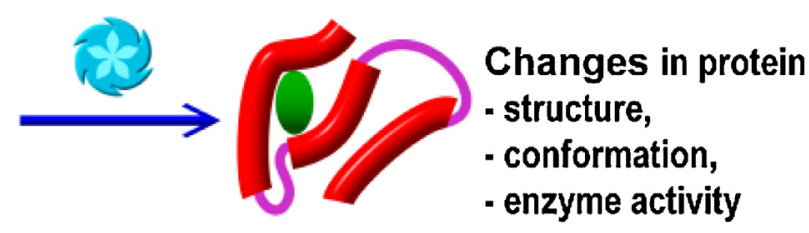

Active site at the surface

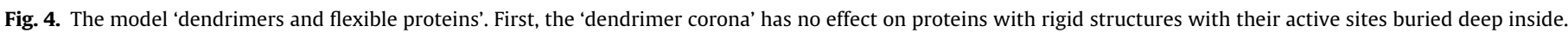

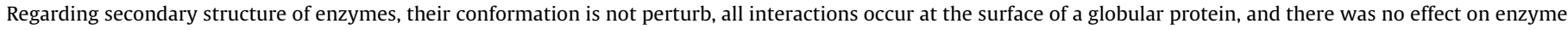

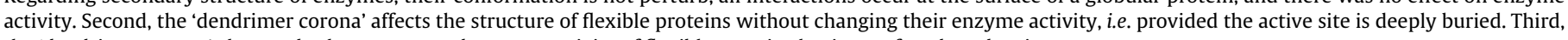
the 'dendrimer corona' changes both structure and enzyme activity of flexible proteins having surface-based active centers.

cell membrane surface. When locks are diffusing, the dendrimer is reaching maximal cooperativity; after the dendrimer makes the first connection, it simply waits for locks to diffuse in the vicinity of available keys to make additional connections. In the absence of diffusion, the optimal configuration can only be obtained by multiple binding and unbinding events, the time-scale for which is prohibitively long [44]. Seemly under in experimental conditions, dendrimers are connected to the surface by a single bridge, but cannot form an additional connection. This is the kinetic origin of limited cooperativity in folated dendrimers, especially for cancer cells overexpressing a multitude of folate receptors [44]. The authors concluded that, if single-stranded DNA on the dendrimer 
is hybridized to the ssDNA attached to the folic acid key, it can significantly increase the multiplicity of binding [44].

\subsection{Molecular modeling studies}

The burst in computer science has led to enhanced molecular modeling studies on interactions between dendrimers and proteins. Giri et al. [22] made the molecular simulation of the interaction between cationic PAMAM G4 dendrimer and human serum albumin and found the importance of HSA interactions with dendrimer inner shell protons. It indicates the possibility of backfolding of dendrimer branches and interaction of internal hydrophobic groups of PAMAM G4 with HSA [22]. Shukla et al. [45] analyzed the interaction between alpha-chymotrypsinogen A and PAMAM dendrimers and found two important effects: (1) enhancement of conformational stability and (2) reduction of protein-protein association due to crowding of dendrimers around the protein surface. In molecular simulation study of Barata et al. [46] the partially glycosylated dendrimers blocked MD-2 (lymphocyte antigen 96) protein and prevented TLR4-MD-2-lipopolysaccharide complex mediated cytokine responses (TRL4 - Toll-like receptor 4). They demonstrated that dendrimer glucosamine forms co-operative electrostatic interactions with residues lining the entrance to MD-2's hydrophobic pocket. Crucially, dendrimer glucosamine interferes with the electrostatic binding of: (i) the 49th phosphate on the di-glucosamine of lipopolysaccharide to Ser118 on MD2; (ii) lipopolysaccharide to Lys91 on MD-2; (iii) the subsequent binding of TLR4 to Tyr102 on MD-2. This is followed by additional co-operative interactions between several of the dendrimer glucosamine's carboxylic acid branches and MD-2 [46]. GonzálezGarcía et al. [47] performed molecular modeling of the interaction between sulfonated carbosilane dendrimers and 3 proteins (bovine serum albumin, myoglobin and lyzozyme). They found that despite its negative net charge, BSA seemed to interact with the dendrimer by electrostatic forces due to local positive sites. In the case of lysozyme, the ability of dendrimer to bind lysozyme was clearly demonstrated using computer modeling. Myoglobin resulted in a huge increase in fluorescence intensity attributed to interactions with dendrimer near the heme group that affected the energy transfer established between Trp residues and the heme group [47]. Interactions between proteins and sulphonate-terminated carbosilane dendrimers, especially at acidic $\mathrm{pH}$, could be the base for proposing a new approach in protein sample preparation based on the application of dendrimers for the selective retention of proteins in a matrix [47].

\section{Dendrimer-protein interactions and diseases}

The potential applications of dendrimers to practical medicine have been extensively reviewed [7-19]. Inhibition of protein-protein interactions by using dendrimers as drugs was analyzed [48]. Our tutorial review regarding the different approaches using nanoparticles (including dendrimers) to treat neurological diseases - Alzheimer's disease, Huntington's disease, Parkinson's disease, ischemia/reperfusion injury, neuroinflammation including cerebral palsy, neurological injury after cardiac surgery and particularly after hypothermic circulatory arrest, and retinal degeneration is in press (Prog Polym Sci). Inhibition of HIV-1 virus is an important problem in treating AIDS. Doménech et al. [49] proposed the disruption of HIV-1 capsid protein oligomerization using dendrimers, and found that gallic acid-triethylene glycol dendrimers of 1 st generation bound to the terminal domain of capsid protein to induce the significant changes in secondary structure conformation. These changes led to disruption of the capsid protein native structure and inhibition of HIV-1 replication in general [49]. These authors mapped the binding site of dendrimers in the terminal domain of capsid protein and found that selected amino residues in helix 9 (consisting of charged amino acids Asp, Lys, Arg, Glu, and hydrophobic - Phe, Thr) are responsible for binding dendrimers to capsid protein [49]. Milowska et al. [50-52] studied interactions between different kinds of dendrimers (cationic PAMAM, phosphorous, carbosilane and viologen-phosphorus) and $\alpha$-synuclein, which is the protein of most importance in many neurodegenerative diseases, e.g., Alzheimer disease and multiple sclerosis; misfolded alfa-synuclein and accumulation of its aggregates are two of the basic components of Lewy bodies observed in degenerated neurons. They found that binding of cationic dendrimers to $\alpha$-synuclein stabilized its secondary structure and conformation, and prevented misfolding and fibril formation [50-52]. Luganini et at. [53] synthesized a series of peptide-derivatized dendrimers consisting of a peptidyl branching core and covalently attached surface functional peptides, and applied them to Herpes Simplex Virus type 1 and type 2 infections. Inhibition of HSV adsorption was explained by the ability of the peptide-derivatized dendrimers to bind to the glycosaminoglycan moiety of cell surface heparan sulfate proteoglycans, thereby blocking virion attachment to target cells [53]. Dendrimers are promising candidates against prion diseases [54]. Cationic dendrimers accumulate together with PrPSc molecules in lysosomes and facilitate dendrimer-mediated PrPSc disaggregation. PAMAM, PPI, and phosphorus dendrimers potentially could remove PrSc from cells [54-56]. Dendrimers can also be considered as potential agents for the treatment of Alzheimer's disease. Klajnert et al. $[57,58]$ found that a 3rd generation of cationic PAMAM dendrimer disaggregated the Alzheimer's peptide, $A \beta$ 1-28. Later, different generations of PAMAM, PPI and phosphorus dendrimers were successfully used to disaggregate amyloid fibrils [59-61]. Palivan et al. [61,62] reviewed in detail protein-polymer systems as reaction spaces at the nano-scale, in which the enzymic reactions take place inside a polymer supramolecular assembly at its interface with the environment or in a combination of both. Dubey et al. [63] synthesized a range of peptide dendrimers to use them as "artificial chaperones"; they found that peptide dendrimers recovered $>90 \%$ of their biological activity with regard to unfolded lipases and amylases. The refolding yields decreased to $14 \%$ in the complexity and hydrophobicity of the dendron/dendrimer. These results indicate the possibility of regulating protein functionality by dendrimers. Dendrimers can be used as a new kind of immunostimulating components (adjuvants) that significantly increase the efficiency of vaccines [12,64]. PAMAM dendrimers have been used as adjuvants for influenza antigen and similar materials; their mid-generations forms are preferred and yield high antibody titer levels with reduced antigen dosage [12,64]. The latest applications of dendrimers are: (1) a strategy to construct high-ordered protein nanowires by electrostatic assembly of cricoid proteins and dendrimers. In this process, PAMAM dendrimers induce electrostatic assembly of electronegative cricoid proteins. The nanostructures that have been designed could act as versatile scaffolds to develop multienzyme-cooperative anti-oxidative systems [65]; (2) a strategy to construct photocontrolled protein nanowires with reversible morphology through photoisomerizable azobenzene-cored dendrimer-evoked protein self-assembly [66]; (3) construction of an GSH sensitive nanocarrier with Angiopep-2 as a dual-targeting group and doxorubicin as the therapeutic drug, made by covalently conjugating them on the periphery of G4 PAMAM, enhancing BBB transportation and drug accumulation in glioma cells [67]; (5) a modified phytoglycogen nanoparticle, Nano-11, having a positive surface charge enabling electrostatic adsorption of negatively charged protein antigens, proposed to activate dendritic cells in vitro and in vivo (as a nano-adjuvant) [68]; (6) an electrostatic self-assembly of binary soft particle co-crystals, 
consisting of apoferritin protein cages and PAMAM dendrimers. The structure and stability of soft particle co-crystals are of major relevance for applications where a high degree of structural control is required; for example, protein-based mesoporous materials, nanoscale multicompartments, and metamaterials [69]; (7) a PAMAM-OH G3 dendrimer developed to remove human islet amyloid polypeptide forms in the islets of Langerhans, a phenomenon associated with type- 2 diabetes affecting millions of people worldwide [70]; (8) tryptophan-based dendrimers that have been synthesized and tested against HIV replication. HIV inhibition can be achieved by the preferred interaction of the compounds with glycoproteins gp120 and gp41 on the HIV envelope $[71,72]$. Bacterial lectins are nonenzymatic sugar-binding proteins involved in the formation of biofilms and the onset of virulence. Bouvier [83] proposed long-time-scale coarse-grained simulations of dendrimers and lectins with a reasoned exploration of the dendrimer sequence space in an attempt to suggest sequences that could maximize multivalent binding to the galactose-specific bacterial lectin LecA. Leire et al. [84] found that cationic gallic acid-triethylene glycol dendrimers can induce the formation of clusters in Vibrio harveyi, an opportunistic marine pathogen. The antibacterial activity of dendrimers is due to their ability to bind and disrupt anionic bacterial membranes, resulting in lysis of bacteria such as Staphylococcus aureus, Pseudomonas aeruginosa, and Escherichia coli [85-87].

\section{Conclusions and remarks}

Nanotechnology and nanoscience are disciplines that combine and cross-link classic fields e.g. chemistry, biology, physics, and programming (molecular modeling) as novel approaches to produce nanomedicine. In this regard, it is very important to understand the basic principles of interaction between nanosystems and the main molecular and biochemical systems of the body, e.g. proteins, nucleic acids, membranes, cells, organs and tissues. Starting from them, we can narrow our topic to nucleic acids and proteins, the products of our genotype. This is a straightforward way to personalized nanomedicine based on genotypic and phenotypic expression of the individual. Now we can summarize that electrostatic force plays the predominant role in 'charged dendrimer - protein' interactions and these interactions depend on the characteristics of both participants: flexibility and surface charge of a dendrimer, rigidity of protein structure and the localization of charged amino acids at its surface. Binding of dendrimers to a protein can change its secondary structure, conformation, intramolecular mobility and functional activity. However, this strongly depends on rigidity versus flexibility of a protein's structure. Based on these fundamental principles in the near future, there are important directions for innovative nanomedicine: (1) drug delivery: using nanomaterials to improve the bioavailability and pharmacokinetics of drugs. Nanotechnology can cross biological barriers to deliver therapeutic agents directly to specific cells and tissues (e.g. in the brain by crossing blood-brain barrier); (2) nano-based therapy: screening and improving therapeutic effects in biological systems (drug biodistribution, action and excretion) by means of 'signalling' nanomaterials; (3) implants and surgery: to offer novel biocompatible coatings for the implants that improve their durability and lifespan, and to repair damaged tissues and organs; (4) imaging of all processes in a body using labeled dendritic nanoconjugates, quantum dots, gold nanoparticles, etc. Related to dendrimer-protein interactions, we expect to produce: (i) high-ordered and photocontrolled protein nanowires as versatile scaffolds to develop multienzyme-cooperative systems; (ii) new nanocarriers based on proteins and dendrimers to cross the blood-brain barrier and to deliver drug to any tissue; (iii) new nano-adjuvants to activate the immune system; (iv) new kinds of nanocarriers based on soft particle co-crystals, protein-based mesoporous materials, nanoscale multicompartments and metamaterials. There will be a continuation of research on the topics of research mentioned above. The realization of these tasks can significantly improve the 'quality of life' in medical care, propose new directions for treatments of some currently untreatable diseases and resistant pathogens, and offer more cost-effective healthcare in developing countries. On the other hand, these objectives must be achieved without compromising safety margins, which remains a major challenge in modern nanotoxicology. In the more distant future we expect at least 3 independent ways for development of innovative nanomedicine: (i) the development of new drugs of common action that have combined effects (e.g. diagnosis and treatment), (ii) the creation of personalized drugs that are based on a patient genotype and are targeted to his/her personal DNA or mRNA (e.g., small nucleic acids - plasmids, siRNA, microRNA), and (iii) 3D-bioprinting of a patient artificial organs.

\section{Acknowledgements}

This work has been supported by grants B15MS-001, B15RM060, M15CO-041 from the Belarusian Republican Foundation for Fundamental Research; from CTQ2011-23245, CTQ-2014-54004$\mathrm{P}(\mathrm{MINECO})$, and Consortium NANODENDMED ref S2011/BMD2351 (CAM) to University of Alcalá. CIBER-BBN is an initiative funded by the VI National R\&D\&i Plan 2008-2011, Iniciativa Ingenio 2010, Consolider Program, CIBER Actions and financed by the Instituto de Salud Carlos III with assistance from the European Regional Development Fund. This work was supported by a Marie Curie International Research Staff Exchange Scheme Fellowship within the 7th European Community Framework Programme, project No. PIRSES-GA-2012-316730 NANOGENE.

\section{References}

[1] J. Adkins, S. Varnum, K. Auberry, R.J. Moore, N. Angell, R. Smith, D. Springer, J. Pounds, Mol. Cell. Proteom. 1 (2002) 947.

[2] Y. Shen, J. Kim, E. Strittmatter, J. Jacobs, D. Camp 2nd, R. Fang, N. Tolié, R Moore, R. Smith, Proteom 5 (2005) 4034.

[3] S. Schutzer, T. Liu, B. Natelson, T. Angel, A. Schepmoes, S. Purvine, K. Hixson, M. Lipton, D. Camp, P. Coyle, R. Smith, J. Bergquist, PLoS One 5 (2010) e10980.

[4] A. Nel, L. Mädler, D. Velegol, T. Xia, E. Hoek, P. Somasundaran, F. Klaessig, V. Castranova, M. Thompson, Nat. Mater. 8 (2009) 543.

[5] J. Wolfram, Y. Yang, J. Shen, A. Moten, C. Chen, H. Shen, M. Ferrari, Y. Zhao, Colloids Surf. B 124 (2014) 17.

[6] M. Dobrovolskaia, A. Patri, J. Zheng, J. Clogston, N. Ayub, P. Aggarwal, B. Neun, J. Hall, S. McNeil, Nanomedicine 5 (2009) 106

[7] D.A. Tomalia, New J. Chem. 36 (2012) 264

[8] S. Mignani, S. El Kazzouli, M. Bousmina, J.P. Majoral, Adv. Drug Deliv. Rev. 65 (2013) 1316.

[9] O. Matthews, A. Shipway, J. Stoddart, Prog. Polym. Sci. 23 (1998) 1

[10] K. Al-Jamal, C. Ramaswamy, A. Florence, Adv. Drug Deliv. Rev 57 (2005) 2238.

[11] S. Svenson, D. Tomalia, Adv. Drug Deliv. Rev. 57 (2005) 2106.

[12] P. Heegaard, U. Boas, N. Sorensen, Bioconjug. Chem. 21 (2010) 405.

[13] S. Mignani, S. El Kazzouli, M. Bousmina, J.P. Majoral, Prog. Polym. Sci. 38 (2013) 993

[14] J.R. Baker Jr., Wiley Interdiscip. Rev. Nanomed. Nanobiotechnol. 5 (2013) 423.

[15] K. Jain, P. Kesharwani, U. Gupta, N.K. Jain, Intern. J. Pharm. 394 (2010) 122

[16] H.F. Krug, Angew. Chem. Int. Ed. Engl. 53 (2014) 12304.

[17] D.A. Tomalia, Macromol. Symp. 101 (1996) 243.

[18] D.A. Tomalia, Aldrichim. Acta 37 (2004) 39.

[19] D.A. Tomalia, H. Baker, J. Dewald, M. Hall, G. Kallos, S. Martin, J. Roeck, J. Ryder, P. Smith, Macromolecules 19 (1986) 2466.

[20] N. Higashi, T. Koga, M. Niwa, ChemBioChem 3 (2002) 448

[21] M.F. Ottaviani, S. Jockusch, N.J. Turro, D.A. Tomalia, A. Barbon, Langmuir 20 (2004) 10238.

[22] J. Giri, M.S. Diallo, A.J. Simpson, Y. Liu, W.A. Goddard III, R. Kumar, G. Woods, ACS Nano 5 (2011) 3456

[23] D. Shcharbin, B. Klajnert, M. Bryszewska, J. Biomater. Sci. Polymer Edn. 16 (2005) 1081.

[24] D. Pagé, D. Zanini, R. Roy, Bioorg. Med. Chem. 4 (1996) 1949.

[25] S. André, P. Ortega, M. Perez, R. Roy, H.-J. Gabius, Glycobiology 9 (1999) 1253.

[26] T. Chiba, T. Yoshimura, K. Esumi, Colloids Surf. A 214 (2003) 157 
[27] E. Froehlich, J.S. Mandeville, C.J. Jennings, R. Sedaghat-Herati, H.A. Tajmir-Riahi, J. Phys. Chem. B 113 (2009) 6986.

[28] L. Giehm, C. Christensen, U. Boas, P.M. Heegaard, D.E. Otzen, Biopolymers 89 (2008) 522.

[29] M.B. Camarada, V. Marquez-Miranda, I. Araya-Duran, A. Yévenes, F. González-Nilo, Phys. Chem. Chem. Phys. 17 (2015) 19001.

[30] N. Martinho, H. Florindo, L. Silva, S. Brocchini, M. Zloh, T. Barata, Molecules 19 (2014) 20424.

[31] T. Peters Jr., All About Albumin: Biochemistry, Genetics and Medical Applications, Academic Press, New York, 1996.

[32] D. Shcharbin, M.F. Ottaviani, M. Cangiotti, M. Przybyszewska, M. Zaborski, M. Bryszewska, Colloids Surf. B 63 (2008) 27.

[33] P. Ruenraroengsak, A.T. Florence, J. Drug Target 18 (2010) 803.

[34] O. Nowacka, D. Shcharbin, B. Klajnert-Maculewicz, M. Bryszewska, Colloids Surf. B 116 (2014) 757

[35] D. Shcharbin, N. Shcharbina, K. Milowska, F.J. de la Mata, M.A. Muñoz-Fernandez, S. Mignani, R. Gomez-Ramirez, J.P. Majoral, M. Bryszewska, Int. J. Pharm. 473 (2014) 599.

[36] D. Shcharbin, M. Ionov, V. Abashkin, S. Loznikova, V. Dzmitruk, N. Shcharbina, L. Matusevich, K. Milowska, K. Gałęcki, S. Wysocki, M. Bryszewska, Colloids Surf. B 134 (2015) 377.

[37] M. Ionov, A. Ihnatsyeu-Kachan, S. Michlewska, N. Shcharbina, D. Shcharbin, J.P. Majoral, M. Bryszewska, Int. J. Pharm. 499 (2016) 247.

[38] E. Gabellieri, G.B. Strambini, D. Shcharbin, B. Klajnert, M. Bryszewska, Biochim. Biophys. Acta 1764 (2006) 1750

[39] M. Ciolkowski, M. Rozanek, M. Szewczyk, B. Klajnert, M. Bryszewska, Biochim. Biophys. Acta 2011 (1808) 2714.

[40] B. Klajnert, M. Bryszewska, Bioelectrochem 55 (2002) 33.

[41] B. Klajnert, L. Stanisławska, M. Bryszewska, B. Pałecz, Biochim. Biophys. Acta 1648 (2003) 115.

[42] D. Shcharbin, M. Janicka, M. Wasiak, B. Palecz, M. Przybyszewska, M. Zaborski, M. Bryszewska, Biochim. Biophys. Acta 1774 (2007) 946

[43] F. Chiba, G. Manna, L.J. Twyman, Org. Biomol. Chem. 8 (2010) 5056

[44] N.A. Licata, A.V. Tkachenko, Phys. Rev. Lett. 100 (2008) 158102.

[45] D. Shukla, C.P. Schneider, B.L. Trout, J. Phys. Chem. Lett. 2 (2011) 1782.

[46] T.S. Barata, I. Teo, S. Brocchini, M. Zloh, S. Shaunak, PLoS Comput. Biol. 7 (2011) e1002095.

[47] E. González-García, M. Maly, F.J. de la Mata, R. Gómez, M.L. Marina, M.C. García, Colloids Surf. B 149 (2017) 196.

[48] S. Mignani, S. El Kazzouli, M. Bousmina, J.-P. Majoral, Chem. Rev. 114 (2014) 1327.

[49] R. Domenech, O. Abian, R. Bocanegra, J. Correa, A. Sousa-Herves, R. Riguera, M.G. Mateu, E. Fernandez-Megia, A. Velázquez-Campoy, J.L. Neira, Biomacromol 11 (2010) 2069.

[50] K. Milowska, T. Gabryelak, M. Bryszewska, A.M. Caminade, J.P. Majoral, Int. J. Biol. Macromol. 50 (2012) 1138.

[51] K. Milowska, J. Grochowina, N. Katir, A. El Kadib, J.P. Majoral, M. Bryszewska, T. Gabryelak, Mol. Pharm. 10 (2013) 1131

[52] K. Milowska, A. Szwed, M. Mutrynowska, R. Gomez-Ramirez, F.J. de la Mata, T. Gabryelak, M. Bryszewska, Int. J. Pharm. 484 (2015) 268.

[53] A. Luganini, S.F. Nicoletto, L. Pizzuto, G. Pirri, A. Giuliani, S. Landolfo, G. Gribaudo, Antimicrob. Agents Chemother. 55 (2011) 3231.

[54] S. Supattapone, H. Wille, L. Uyechi, J. Safar, P. Tremblay, F.C. Szoka, F.E. Cohen, S.B. Prusiner, M.R. Scott, J. Virol. 75 (2001) 3453.

[55] J. Solassol, C. Crozet, V. Perrier, J. Leclaire, F. Béranger, A.M. Caminade, B. Meunier, D. Dormont, J.P. Majoral, S. Lehmann, J. Gen. Virol. 85 (2004) 1791.
[56] S. Supattapone, J.R. Piro, J.R. Rees, CNS Neurol. Disord. Drug Targets 8 (2009) 323.

[57] B. Klajnert, M. Cortijo-Arellano, M. Bryszewska, J. Cladera, Biochem. Biophys. Res. Commun. 339 (2006) 577.

[58] B. Klajnert, M. Cortijo-Arellano, J. Cladera, M. Bryszewska, Biochem. Biophys. Res. Commun. 345 (2006) 21.

[59] P.M.H. Heegaard, H.G. Pedersen, J. Flink, U. Boas, FEBS Lett. 577 (2004) 127.

[60] B. Klajnert, M. Cortijo-Arellano, J. Cladera, J.P. Majoral, A.M. Caminade, M. Bryszewska, Biochem. Biophys. Res. Commun. 364 (2007) 20.

[61] S.M. Chafekar, H. Malda, M. Merkx, E.W. Meijer, D. Viertl, H.A. Lashuel, F. Baas, W. Scheper, ChemBioChem 8 (2007) 1857.

[62] C.G. Palivan, O. Fischer-Onaca, M. Delcea, F. Itel, W. Meier, Chem. Soc. Rev. 41 (2012) 2800 .

[63] P. Dubey, S. Gautam, P.P.P. Kumar, S. Sadanandan, V. Haridas, M.N. Gupta, RSC Adv. 3 (2013) 8016.

[64] T. Toyokuni, S. Hakomori, A.K. Singhal, Bioorg. Med. Chem. 2 (1994) 1119.

[65] H. Sun, L. Miao, J. Li, S. Fu, G. An, C. Si, Z. Dong, Q. Luo, S. Yu, J. Xu, J. Liu, ACS Nano 9 (2015) 5461.

[66] H. Sun, L. Zhao, T. Wang, G. An, S. Fu, X. Li, X. Deng, J. Liu, Chem. Commun. 52 (2016) 6001.

[67] Z. Xu, Y. Wang, Z. Ma, Z. Wang, Y. Wei, X. Jia, Polym. Chem. 7 (2016) 715.

[68] F. Lu, A. Mencia, L. Bi, A. Taylor, Y. Yao, H. HogenEsch, J. Control. Release 204 (2015) 51

[69] V. Liljestram, J. Seitsonen, M. Kostiainen, ACS Nano 9 (2015) 11278.

[70] E. Gurzov, B. Wang, E. Pilkington, P. Chen, A. Kakinen, W. Stanley, S.A. Litwak, E.G. Hanssen, T.P. Davis, F. Ding, P.C. Ke, Small 12 (2016) 1615.

[71] E. Rivero-Buceta, E. Doyaguez, I. Colomer, E. Quesada, L. Mathys, S. Noppen, S Liekens, M. Camarasa, M. Pérez-Pérez, J. Balzarini, A. San-Félix, Eur. J. Med. Chem. 106 (2015) 34.

[72] K.H. Schlick, C.K. Lange, G.D. Gillispie, M.J. Cloninger, J. Am. Chem. Soc. 131 (2009) 16608.

[73] D. Shcharbin, B. Klajnert, V. Mazhul, M. Bryszewska, J. Fluoresc. 15 (2005) 21.

[74] E. Pedziwiatr, D. Shcharbin, L. Chonco, P. Ortega, F.J. de la Mata, R. Gómez, B. Klajnert, M. Bryszewska, M.A. Muñoz-Fernandez, J. Fluoresc. 19 (2009) 267.

[75] S. Sekowski, A. Buczkowski, B. Palecz, T. Gabryelak, Spectrochim. Acta Part A 81 (2011) 706.

[76] D. Shcharbin, M. Jokiel, B. Klajnert, M. Bryszewska, Bioelectrochem 68 (2006) 56.

[77] S.P. Zhong L.Y.L. Yung J. Biomed. Mater. Res. Part A 91A (2009) 114

[78] M. Ciolkowski, I. Halets, D. Shcharbin, D. Appelhans, B. Voit, B. Klajnert, M. Bryszewska, New J. Chem. 36 (2012) 1992.

[79] M. Ciolkowski, B. Pałecz, D. Appelhans, B. Voit, B. Klajnert, M. Bryszewska, Colloids Surf. B 95 (2012) 103.

[80] M. Ciolkowski, M. Rozanek, M. Bryszewska, B. Klajnert, Biochim. Biophys. Acta 1834 (2013) 1982.

[81] J. Lin, W. Hua, Y. Zhang, C. Li, W. Xue, J. Yin, Z. Liu, X. Qiu, Biochim. Biophys. Acta 1850 (2015) 419.

[82] H.M. Zhang, K. Lou, J. Cao, Y.Q. Wang, Langmuir 30 (2014) 5536

[83] B. Bouvier, J. Chem. Inf. Model. 56 (2016) 1193.

[84] E. Leire, S.P. Amaral, I. Louzao, K. Winzer, C. Alexander, E. Fernandez-Megia, F. Fernandez-Trillo, Biomater. Sci. 4 (2016) 998.

[85] B.M. Paddle, J. Appl. Toxicol. 23 (2003) 139.

[86] B. Klajnert, J. Janiszewska, Z. Urbanczyk-Lipkowska, M. Bryszewska, D. Shcharbin, M. Labieniec, Int. J. Pharm. 309 (2006) 208.

[87] P.M. Heegaard, U. Boas, Recent Pat. Antiinfect. Drug Discov. 1 (2006) 331. 